\title{
Parish Records from Namibia 1925-1990 - An Attempt to Analyze Fertility and Mortality in Ovamboland
}

\section{VEIJO NOTKOLA}

\author{
Senior Researcher \\ Finnish Institute of Occupational Health \\ Kuopio, Finland and \\ Population Research Unit \\ University of Helsinki \\ Helsinki, Finland
}

\begin{abstract}
The general aim of the study is to describe and to try to understand the population development (mortality and fertility) in Ovamboland in North-Namibia. Parish records are used as a primary source. The family reconstruction method based on marriage cohorts has been used. The data includes about 7,000 marriages and 27,000 children. Administrative and missionary records were used especially in interpretation of research results. According to the results both a clear decline and increase in fertility have occurred during 1930-1980 although fertility has been all the time close to natural fertility. Mortality declined in the 1950 s in Ovamboland. The main cause for the mortality decline was probably the health care system built by the missionaries. At the same time, however, there was no more bad famines in the area during the 1950 s and in general the nutrition level also improved during the 1950 s.
\end{abstract}

Keywords: fertility, mortality, family reconstruction method, Namibia

\section{Introduction and the aims of the study}

Population increase in Africa is particularly high. It is estimated that at the beginning of the next century the total fertility rate in Africa will still be over five, when it is below three in other parts of the world. The fertility transition has also started in Africa, but the process is slow and the high population increase will be causing social and economic problems (Leridon and Ferry 1985; Freedman and Blanc 1992; McNicoll 1992; Robinson 1992; Caldwell et al. 1992). Additional research is needed for a deeper understanding of the causes of high fertility and mortality in Africa. The population data from Namibia offers good possibilities for analyzing and understanding both fertility and mortality development over quite a long period.

Population censuses have been carried out in Namibia since 1921 in intervals of about 10 years, but their reliability has not been tested. The 1991 Population and Housing Census was the first census after the country's independence. This 1991 census 
was carried out from 21 October to 8 November 1991 covering population living in households, as well as those in institutions. The collected data covered demographic, social, economic, migration, fertility, and infant mortality items (see Republic of Namibia 1991).

The 1991 Population Census will give extremely important information about basic population questions in Namibia. A second very important data set collected in Namibia is the Demographic and Health Survey which was carried out at the end of 1992 and which will also provide information about population development in Namibia.

The role of the Evangelical Lutheran Church in Namibia (hereafter ELCIN) is important. ELCIN has about half a million members and is divided into 92 parishes. The majority of these parishes are located in the northern part of the country following the overall distribution pattern of the Namibian population. According to the 1991 census more than half of the 1.4 million inhabitants live in the north in an area which covers only about one fifth of the surface area of the country. ELCIN uses the same system for registering vital statistics as the Finnish church. The system was adopted at the end of the last century and is still basically the same. However, this data has never been used for comparison or other purposes in Namibia or elsewhere.

There is no information available on how useful or reliable the parish data are as a source of population data and for understanding or describing population development (fertility and mortality levels and trends in $1920-1990$ ) in Namibia. On the other hand, it is a well-known fact that we do not have population information about almost any African country where we could analyze population development (fertility and mortality) starting from the beginning of this century. Even regarding normal adult mortality in African countries, evidence is scanty ( see Timaeus 1991a).

The general aim of the study is to describe the population development (fertility and mortality) of Namibia for the period 1920-1990, which is impossible with any other source. Only very rough, unreliable estimates given by the South African colonial administration are currently available. The first aim of the study is to evaluate the reliability of parish record data. The second aim is to analyze the level of mortality (childhood and adult mortality) and the level of fertility in Namibia during 1920 1980 .

\section{Materials and methods}

Geographically the study concentrates on Ovamboland. Ovamboland lies in Northeast Namibia close to the Angolan border. The Ovambos are the original inhabitants of Ovamboland (Tuupainen 1970). At the beginning of this century there were eight Ovambo tribes living in Ovamboland: the Uukwanyama, Ondonga, Uukwambi, Ongandjera, Ombalantu, Uukwaludhi, Uukolonkadhi, and Elunda (Tuupainen 1970). During the 1960s only the Ondonga, Ongandjera, and Uukwaludhi tribes had hereditary chieftainship based on matrilineal succession (Tuupainen 1970).

In this study Evangelical Lutheran Church parish record data from Ovamboland, North Namibia, will be used as a primary source. Finnish missionaries started their work in Ovamboland already during the 1870 s. Parish records include several different registers, e.g. a list of deaths, births, marriages and migration and they also include a main register where people are listed in families. The earliest registers are from the 1880 s when the first Christians were baptized. In the central parts of North Namibia about 40-50 percent of the estimated total population were members of the Evangelical Lutheran Church in Namibia in the 1950s (Table 1 and Siiskonen 1995). At the moment, the figure is about 80 percent.

Missionary work in Ovamboland started in Ondonga and soon after in Uukwambi. 
T a b l e 1. Population development and the growth of the Lutheran church in Ovamboland, in the Ondonga, and Uukwambi areas 1933-1960.

$\begin{array}{lcccccc}\text { Year } & \text { Population } & \begin{array}{c}\text { Ondonga } \\ \text { Lutherans }\end{array} & \% & \text { Population } & \begin{array}{c}\text { Uukwambi } \\ \text { Lutherans }\end{array} & \% \\ 1933 & 34,195 & 13,584 & 40 & 11,405 & 1,603 & 14 \\ 1951 & 53,404 & 26,970 & 51 & 22,239 & 7,292 & 33 \\ 1960 & 68,601 & 47,419 & 69 & 28,341 & 14,060 & 50\end{array}$

Sources: Population data is based on census information: Ovamboland Census, 1933, NAO Vol. 23, 15/2, Nan; Bruwer, J.P., 'The Kunanyama of South West Africa (MA thesis, University of Stellenbosch, 1961), p. 11; Report of the Commission of Enquiry into South West African Affairs 19621963, (Odendaal Commission) (Pretoria, 1964), p. 15.

The growth of the Lutheran Church is based on the Statistical Tables of the Finnish Mission Field in Ovamboland, 1933, 1951, and 1960, AEL.

In Ondonga missionary work had been practiced since 1870 . The most tolerant of the Owambo kings and headmen towards Christianity were the kings of the Ondonga. The situation was not as good in Uukwambi and in addition the Catholics started their work during the 1920 s.

In this study we are going to concentrate on four areas in analyzing fertility and mortality during 1920-1980 in Ovamboland, North Namibia. First in preparation for the actual research the parish records of Oshigambo (Ondonga area and tribe), Elim (Uukwambi), Okahao (Ongandjera), Tsandi (Uukwaludhi), and Nakayale (Ombalan$t u$ ) were microfilmed. All these parishes are situated in the areas of different tribes. The second reason for selecting these parishes is that they are old and third that their records are in good condition.

The family reconstruction method based on marriage cohorts (family histories) has been used in collecting data from the microfilmed registers. The data entry was done at the University of Joensuu. The data includes 6,373 marriages and 27,181 children. The number of deaths in the whole data set under age 25 was about 2,006 and above age 25, 1,436 (see Appendix). The follow-up of marriage cohorts was started in 1925 and the last marriage cohorts included were from the year 1975. The civil war started in the middle of the 1970 s.

The analysis of parish records data was based mostly on normal demographic measurements such as total fertility rates and age-adjusted mortality rates. The total fertility rate is not fully comparable to the normal total fertility rate because the calculations are based on the fertility of marriage cohorts. On the other hand, it is not fully comparable to the total marital fertility rate because the follow-up of women started from the date of baptism, not from the date of marriage. The risk population was defined by calculating person years lived in a certain age group per year, taking account the age of baptism, death, and out-migration and change of religion. Children were excluded from the data if the only information available was the birth or the baptism of the child.

For the reliability evaluation of the parish record data, the results from the 1991 Population and Housing Census as well as from the 1992 Demographic and Health Survey in Namibia were used (Namibia. Demographic and Health Survey 1992 and Republic of Namibia. 1991 Population and Housing Census). Additional regional census material provided by Central Statistics Office of Namibia was also used.

In analyzing mortality and fertility based on census data and demographic health surveys demographic methods developed for the purposes of developing countries were used (see Hill 1984 and Timaeus 1991). Fertility estimations from data of the Namibia Population and Housing Census 1991 were made by using the Brass method based on 
F i g u r e 1. General fertility rate (15-49) in Ovamboland 1927-1977 (5 year moving average). Marriage cohorts 1925-1975.

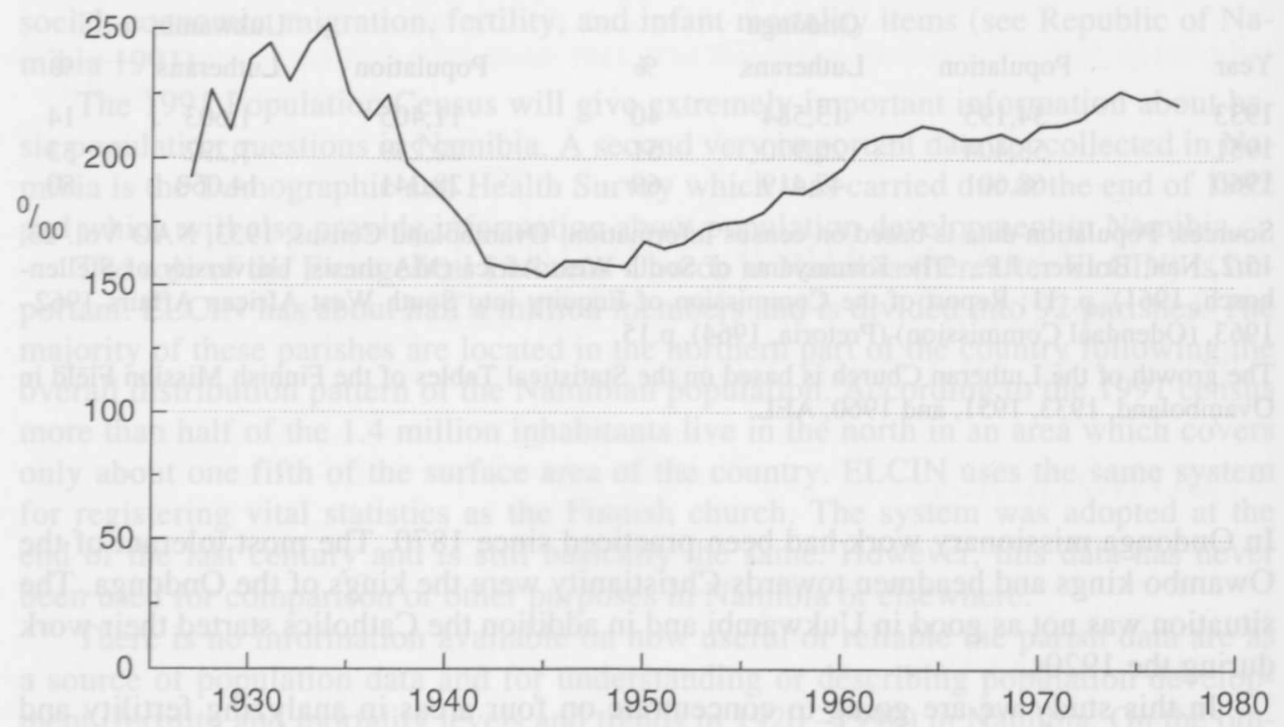

comparison of period fertility rates with reported average parities, called the P/F method. Indirect child mortality estimation was done by using Trussel's variant of the original Brass method (United Nations 1983). Direct calculations of age-specific fertility rates from retrospective birth histories in the Namibia Demographic and Health Survey 1992 were also made (see Verma 1980).

\section{Results}

The mean age at first marriage has been high among Ovambos. Among the first marriage cohorts in 1925-1944 it was about 25 years among males and about 20 years among females. Since the 1955 marriage cohorts it has been almost 30 years among males and about 24 years among females. In the birth cohort 1946-1955 the mean age at first marriage was 25.7 years for males and 22.0 years for females. Compared with other African figures these average ages at first marriage are high. According to the Namibian Demographic and Health Survey 1992 the median age at first marriage for women in the Northeast region was 23 years.

\section{Fertility}

The parish register data suggest that there occurred both a substantial decline and an increase in fertility during 1930-1980. According to Figure 1, the total fertility rate was close to 8 during the 1930 s but clearly declined during the $1940 \mathrm{~s}$. The total fertility rate was approximately 6 during 1940 s and 1950s in Ovamboland. Since 1960 fertility increased. During the 1970 s the total fertility rate was almost 7 in Ovamboland and continued to increase during the 1970 s. The general fertility rate and the total fertility rate have behaved quite similarly (Figure 1 and 2 ). In addition, the total fertility rate is probably slightly too low. The reason is that the data probably do not include all the deceased children. Based on childhood mortality (1-4 years) and model life 
Fi g u r e 2. Total fertility rate in Ovamboland 1929-1977 (5 year moving average) Marriage cohorts 1925-1975.

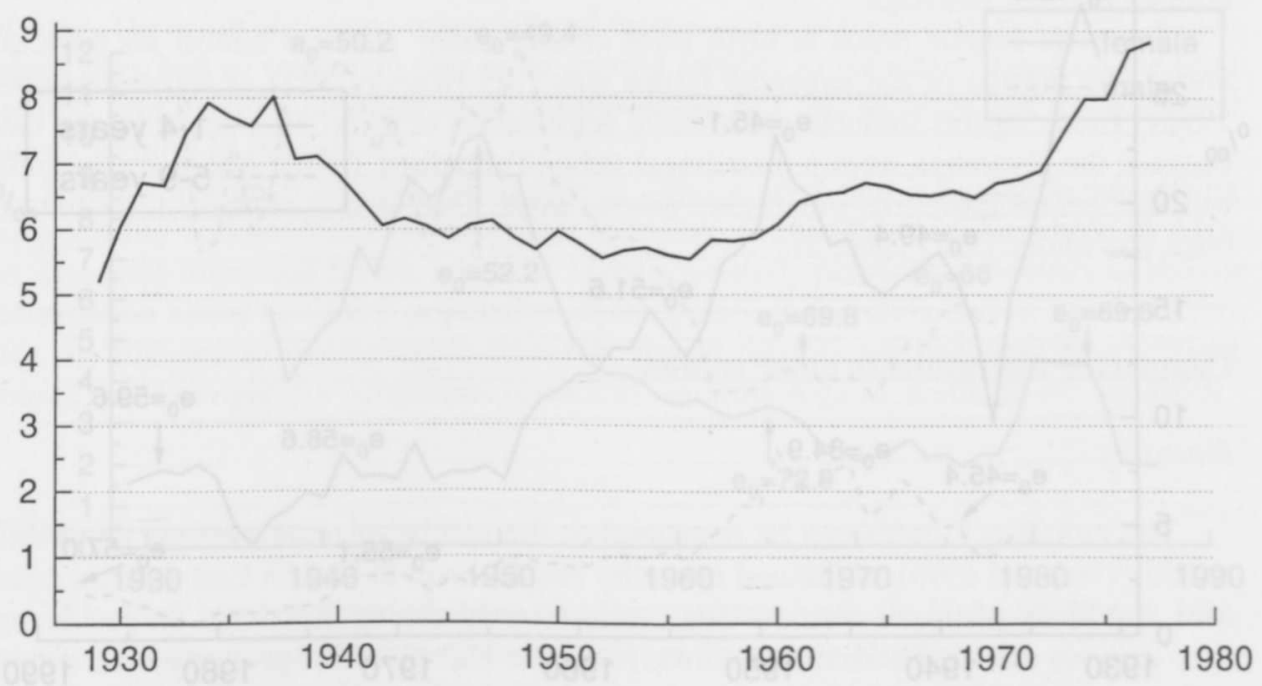

tables (Coale and Demeny 1983), infant mortality was estimated to be about 110-140/ 1,000 . In the research material the infant mortality level was about $40-90 / 1,000$. It can roughly be estimated that the completed mean family size in the parish register material would be about 0.5 children higher if children who had died and were missing from the records had been added.

According to the Namibian Demographic and Health Survey 1992 the total fertility rate among rural Protestants in Oshivambo was approximately 6.8. Based on the 1991 Housing and Population Census the total fertility rate in Oshigambo was 6.4, in Elim 5.7, in Tsandi 5.1 and Okahao 5.6. Based on these results comparison with parish register data showed that no great changes in fertility had occurred in Ovamboland since the 1970 s.

\section{Mortality}

Childhood mortality for 1-4 years olds and 5-9 years olds were analyzed separately. In addition adult mortality for males and females 15-59 years was analyzed. Infant mortality was not analyzed due to the missing deceased children. The main result both from the adult mortality and according to the childhood mortality was that mortality has clearly declined in Ovamboland after 1950. Life expectancy at birth based on childhood mortality was about 35-49 years during the 1930s and 1940s in Ovamboland. During the 1950 s the life expectancy has been close to 50 years in Ovamboland. After 1955 it was over 50 years and at the beginning of the 1980 s it was close to 60 years. However the real level of mortality was probably higher than that calculated from the data. Adult mortality developed similar to childhood mortality. Mortality was probably at a constant level during the 1930s and the 1940s, but it started to decline after 1950. The difference between males and females was negligible before 1950, but after that it seemed that the mortality of males was higher than the mortality of females. However, the quality of data might be different by sex in parish register data and this result needs to be studied more carefully. Comparison of adult and childhood 
F i g u re 3. Childhood mortality in Ovamboland 1931-1988 (5-year moving average)

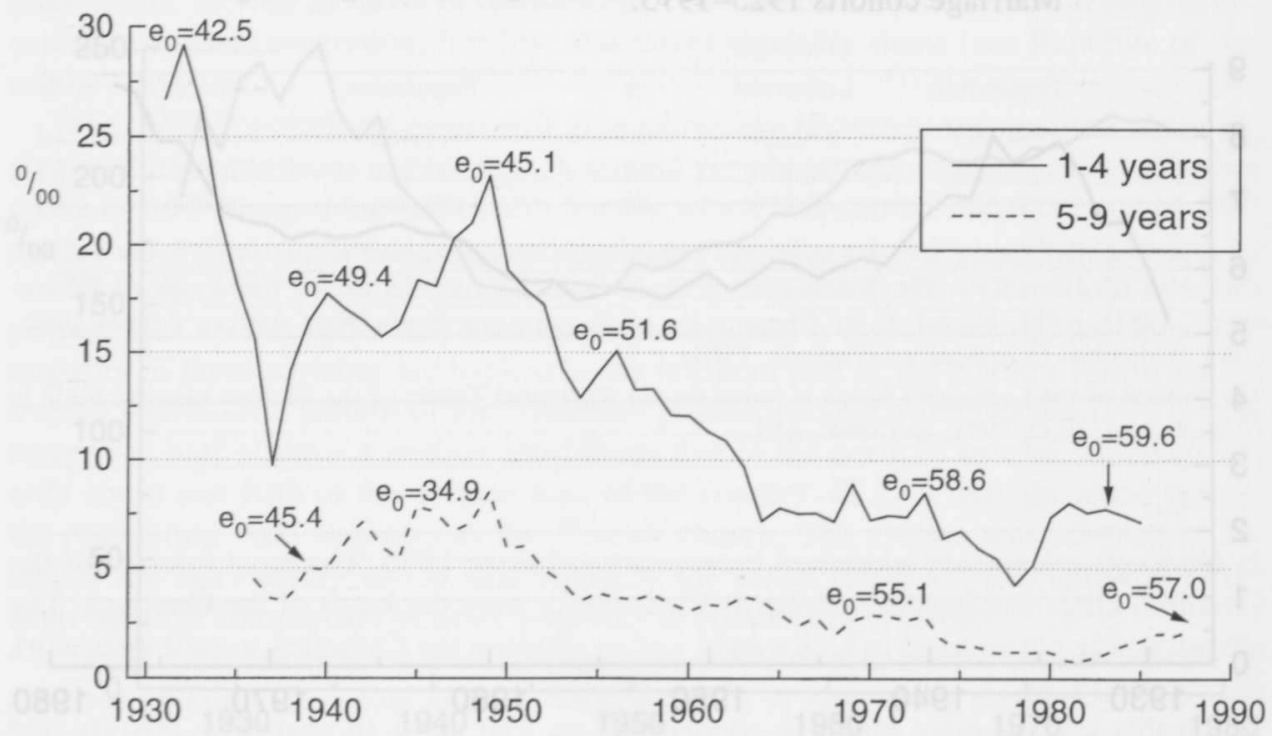

T a b l e 2. Oshakati District in North Namibia. Total mortality level and the reference time before the survey. Indirect mortality estimation based on Trussel's variant of the original Brass method from data of the Namibia Population and Housing Census 1991.

$l(x) \quad$ Coale-Demeny mortality level Reference period

$\begin{array}{lll}l(1) & 18.5 & 0.9\end{array}$

$\begin{array}{lll}l(2) & 18.1 & 2.1\end{array}$

$\begin{array}{lll}l(3) & 17.9 & 3.9\end{array}$

$\begin{array}{lll}l(5) & 17.8 & 6.1\end{array}$

$\begin{array}{lrr}l(10) & 18.0 & 8.5\end{array}$

$\begin{array}{llr}l(15) & 17.7 & 11.2\end{array}$

$l(20) \quad 17.5 \quad 14.3$

mortality showed that the level of adult mortality was lower than the level of childhood mortality.

Indirect mortality estimation from data of the Namibia Population and Housing Census 1991 showed that life expectancy at birth among females was approximately 60-62 years depending on the time reference before the survey (Table 2). Correspondingly, among males, life expectancy values at birth were 56.5-58.8 (Coale and Demeny, West). These results also indicate that mortality has not declined during the period 1971-91. The same results can be found using the parish register data (Figure 3 and 4).

Life expectancy at birth at the mortality level 18 according to the Coale and Demeny West for males is 58.8 and for females 62.0 years. Probabilities of surviving from birth, $l(x)$, estimated from Namibia Census, have been converted into mortality levels by interpolating between the closest values of $l(x)$ in Coale-Demeny West model life tables. The reference period is an estimate of the number of years preceding the survey date to which the mortality estimate refer. 
Fig u re 4. Age-adjusted death rates for males and females aged 15-59 years in Ovamboland 1932-1987 (5-year moving averages).

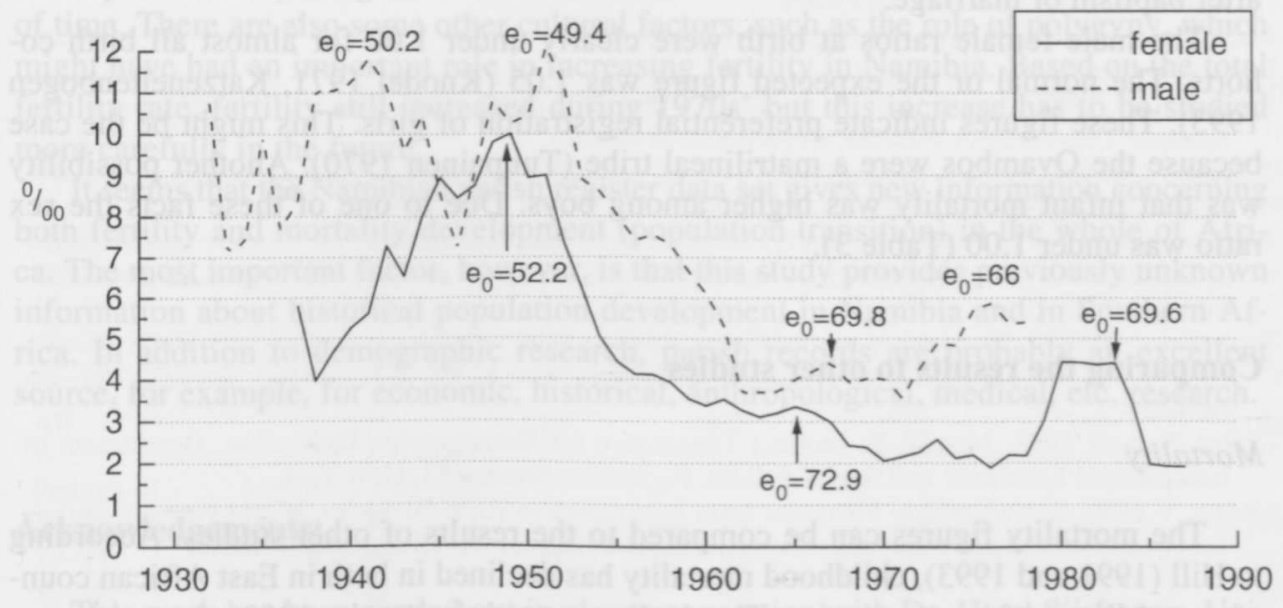

$\mathrm{T}$ a b l e 3. The sex ratio at birth (boys/girls) by birth cohort in parish register data in Ovamboland by birth cohort 1900-1990.

$\begin{array}{lcl}\text { Birth cohort } & \text { Sex ratio } & (\mathrm{N}) \\ 1900-1929 & 117 & (590) \\ 1930-1939 & 93 & (1,884) \\ 1940-1949 & 94 & (3,172) \\ 1950-1959 & 95 & (5,775) \\ 1960-1969 & 99 & (8,155) \\ 1970-1979 & 97 & (6,001) \\ 1980- & 95 & (1,603) \\ \text { All } & 97 & (27,180)\end{array}$

\section{Discussion}

\section{Quality of data}

There are several different kinds of problems when the parish records are used. First, the data includes only the Christian population and the population development of the Christians might be quite different from the other part of the society. In addition birth dates are not always reliable, especially for adults prior to 1940. In this data $0.8 \%$ of the birth rates were missing among children, but among the adults the rate was about $13 \%$. In mortality analysis only those adults were included whose birth date was known. Persons were also excluded from the data if the only information about the person was the marriage date. In addition, exclusion from data occurred if the follow-up information from the marriage according to the main book was poor. The mortality follow-up was started after the marriage date or after the baptism date.

In addition, children who died before baptism do not appear (Feltz 1990). This fact affects both childhood mortality and fertility. The mean age at baptism among children was about 6 months and it seemed to be higher among first birth cohorts during the 1930s. In the adult population the mean age of baptism was almost 18 years among males and among females the figure was about 12 years. For this reason mortality was analyzed only among baptized children and the mortality follow-up was started after 
the marriage date also in the case of children. All children of those adults were excluded for whom the follow-up data was poor. Among females fertility was analyzed after baptism or marriage.

The male-female ratios at birth were clearly under 1.00 for almost all birth cohorts. The normal or the expected figure was 1.05 (Knodel 1971, Katzenellenbogen 1993). These figures indicate preferential registration of girls. This might be the case because the Ovambos were a matrilineal tribe (Tuupainen 1970). Another possibility was that infant mortality was higher among boys. Due to one of these facts the sex ratio was under 1.00 (Table 3 ).

\section{Comparing the results to other studies}

\section{Mortality}

The mortality figures can be compared to the results of other studies. According to Hill (1991 and 1993), childhood mortality has declined in both in East African countries and West African countries. The decline started during the 1950s. In parish register data we can find a similar decline. However Hill does not give any clear explanations why childhood mortality has declined. In adult mortality it is not possible to find a clear decline in mortality in all countries similar to that in childhood mortality. However the rapid reduction in the death rates of adults has been achieved by many West and Central African countries (Timaeus 1991b). Also in Namibia adulthood mortality declined. According to the preliminary analysis there were several possible explanations why mortality declined in North Namibia. There were no more bad famines in the area during the 1950s and, in general, the nutrition level improved although the area was overpopulated. At the same time the level of health care improved and bad epidemics were avoided. However, malaria was endemic and various infectious diseases were present in the area. In addition the water situation improved and the general infrastructure (roads) improved. The educational level also improved. All these factors probably played an important role in decreasing mortality. Mortality has not declined any more during the 1970s and 1980s. During this period there was a civil war in Namibia.

\section{Fertility}

At the same time that mortality was declining fertility started to increase. It is also important to see that there was a clear decline in fertility during the 1940 s. One possible reason for the decline in fertility during the 1940 s was sexually transmitted diseases. According to written sources, these diseases have been present in North Namibia since at least the beginning of this century (Finnish Evangelical Lutheran Mission Archives and Tuupainen 1970 ). During the 1950s out-migration increased due to contract labor. This might be one reason why sexually transmitted diseases might have increased. Probably, however, the main cause of declining fertility has been the increased use of the contract labor from Ovamboland during the 1950s. This increased the mean age at marriage and also led to a lower frequency of intercourse. On the other hand, the increase in fertility during the 1960 s has to be studied more carefully before any explanations can be given, although the improved health care system during the 1960 s might be one explanation. It is a well-known fact that sterility has been a great problem in Sub-Saharan Africa (Larsen and Menken 1991). There is also some evidence that Herero (living in northwestern Botswana close to the Namibian border) 
fertility has increased dramatically in recent decades (Pennington 1992). An additional possibility is that breastfeeding habits have changed due to modernization or missionary work, but during the 1990 s almost all children were breastfed for some period of time. There are also some other cultural factors, such as the role of polygyny, which might have had an important role in increasing fertility in Namibia. Based on the total fertility rate, fertility still increased during 1970s' but this increase has to be studied more carefully in the future.

It seems that the Namibian parish register data set gives new information concerning both fertility and mortality development (population transition) in the whole of Africa. The most important factor, however, is that this study provides previously unknown information about historical population development in Namibia and in Southern Africa. In addition to demographic research, parish records are probably an excellent source, for example, for economic, historical, anthropological, medical, etc. research.

\section{Acknowledgements:}

This work has been carried out in close cooperation with Dr. Harri Siiskonen, University of Joensuu and the Evangelical Lutheran Church in Namibia.

The United Nations University, Wider has supported this study

\section{References}

Caldwell, J., I.O.Orubuloy and P. Caldwell. 1992. Fertility decline in Africa: a new type of transition. Population and Development Review 18(2):211-242.

Coale, A. and P. Demeny. 1983. Regional Model Life Tables and Stable Populations. Academic Press. New York.

Feltz, G.1990. Catholic missions, mentalities, and quantitative history in Burundi, ca 1900-1962. Demography from Scanty Evidence: Central Africa in the Colonial Era, edited by B. Fetter, pp. 113129. London: Lynne Rienner Publisher.

Finnish Evangelical Lutheran Mission Archives. Minutes of Missionary Conferences in Africa. HHA.Vol 19-33. National Archive. Finland

Freedman, R. and A.K. Blanc.1992. Fertility transition: an update. International Family Planning perspectives 18(2):44-50.

Hill, K. 1984. An Evaluating of indirect methods for estimating mortality. In: Methodologies for the Collection and Analysis of Mortality Data: proceedings of a seminar at Dakar, Senegal, July 710, 1981, edited by J.Vallin, J. Polland and L. Heligman, pp.144-77. Liège: IUSSP.

Hill, A. 1991. Infant and child mortality: levels, trends, and data deficiencies. In: Disease and Mortality in Sub-Saharan Africa, edited by R. Feachem and D. Jamison. Oxford, England: Oxford University Press.

Hill, A. 1993. Trends in childhood mortality. In: Demographic Change in Sub-Saharan Africa, edited by K. Foote, K. Hill and G. Martin, pp. 153-217. Washington, D.C.: National Academy Press.

Katzenellenbogen, J., D. Yach, and R.E. Dorrington. 1993. Mortality in a rural South African mission, 1837-1909: an historical cohort study using church records. International Journal of Epidemiology 22:965-75.

Knodel, J. 1970. Two and a half centuries of demographic history in a Bavarian village. Population Studies 24(3):353-76.

Larsen, U. and J. Meneken. 1991. Individual-level sterility: a new method of estimation with application to Sub-Saharan Africa. Demography 28(2):229-49.

Leridon, H. and B. Ferry. 1985. Biological and traditional restraints of fertility. In: Reproductive Change in Developing Countries, edited by J. Cleland and J. Hobcraft, pp. 139-64. London: Oxford University Press

McNicoll, G. 1992. The United Nations' long-range population projections. Population and Development Review 18(2):333-340.

Namibia. Demographic and Health Survey 1992. Ministry of Health and Social Services. Windhoek 1993. 
Pennington, R. 1992. Did food increase fertility? Evaluation of !Kung and Herero history. Human Biology 64: 497-521.

Republic of Namibia 1993. 1991 Population and Housing Census. National Planning Commission. Windhoek: Central Statistical Office.

Robinson, W.R.1992. Kenya enters the fertility transition.

Population Studies 46(3):445-457.

Siiskonen, H. 1995. Migration in the Oshigambo and Elim parish, Owambo, 1925-1935. Manuscript. Joensuu: University of Joensuu, Department of History.

Timaeus, I.M. (a) 1991 (a). Measurement of adult mortality in less developed countries: a comparative review. Population Index 57(4):552-68.

Timaeus, I.M. 1991 (b): Adult mortality: levels, trends, and data sources. In: Disease and Mortality in Sub-Saharan Africa, edited by R. Feachem and D. Jamison, pp. 87-100. Oxford, England: Oxford University Press.

Tuupainen, M.1970. Marriage in a matrilinear African tribe: a social anthropologial study of marriage in the Ondonga tribe in Ovamboland. Transactions of the Westermarck Society, Vol. 18. Helsinki.

United Nations 1983. Manual X. Indirect Techniques for Demographic Estimation. Department of International Economic and Social Affairs. Population Studies 81. New York .

Verma, V.1980. Basic Fertility Measures from Retrospective Birth Histories. World Fertility Survey Technical Bulletins 4. Voorburg, The Netherlands: International Statistical Institute.

\section{Appendix. The number of marriages, births and deaths by parish in final data.}

$\mathrm{T}$ a ble 1 . The number of marriages by parish and marriage cohorts 1925-1975 in parish register data in Ovamboland

$\begin{array}{lcccccr}\text { Marriage cohort } & \text { Elim } & \text { Nakayale } & \text { Okahao } & \text { Oshigambo } & \text { Tsandi } & \text { All } \\ 1925-1935 & 247 & 74 & 78 & 134 & 94 & 627 \\ 1936-1945 & 345 & 77 & 155 & 242 & 84 & 903 \\ 1946-1955 & 544 & 186 & 354 & 311 & 187 & 1582 \\ 1956-1965 & 474 & 220 & 418 & 426 & 343 & 1881 \\ 1966-1975 & 234 & 151 & 500 & 317 & 178 & 1380 \\ \text { All } & 1,844 & 708 & 1,505 & 1,430 & 886 & 6,373\end{array}$

$\mathrm{T}$ a b 1 e 2 . The number of births by birth cohort in parish register data in Ovamboland. Marriage cohorts 1925-1975

Children of the couple or one of the parents

$\begin{array}{lrrrrrr}\text { Birth cohort } & \text { Elim } & \text { Nakayale } & \text { Okahao } & \text { Oshigambo } & \text { Tsandi } & \text { All } \\ -1929 & 210 & 79 & 81 & 157 & 63 & 590 \\ 1930-1939 & 826 & 265 & 219 & 338 & 237 & 1,885 \\ 1940-1949 & 1,228 & 362 & 631 & 585 & 366 & 3,172 \\ 1950-1959 & 1,756 & 768 & 1,291 & 1,071 & 889 & 5,775 \\ 1960-1969 & 1,953 & 1,135 & 2,301 & 1,621 & 1145 & 8,155 \\ 1970-1979 & 1,089 & 567 & 2,220 & 1,348 & 777 & 6,001 \\ 1980- & 265 & 171 & 598 & 351 & 218 & 1,603 \\ \text { All } & 7,327 & 3,347 & 7,341 & 5,471 & 3,695 & 27,181\end{array}$


$\mathrm{T}$ a b l e 3 . The number of deaths by parish among children and among parents over 24 years in parish register data in Ovamboland among marriage cohorts 1925-1975

\begin{tabular}{lrrrrrr} 
Age & \multicolumn{5}{c}{ Parish } \\
Children & Elim & Nakayale & Okahao & Oshigambo & Tsandi & All \\
0 & & & & & & \\
$1-4$ & 227 & 116 & 171 & 178 & 83 & 775 \\
$5-9$ & 172 & 103 & 158 & 191 & 100 & 724 \\
$10-14$ & 52 & 24 & 54 & 62 & 28 & 220 \\
$15-19$ & 30 & 8 & 16 & 34 & 10 & 98 \\
$20-24$ & 33 & 10 & 20 & 24 & 10 & 97 \\
$25-$ & 21 & 8 & 34 & 23 & 6 & 92 \\
All & 40 & 15 & 44 & 66 & 13 & 178 \\
& 575 & 284 & 497 & 578 & 250 & 2184 \\
Parents & & & & & & \\
$25-29$ & 28 & 9 & 27 & 26 & 11 & 101 \\
$30-34$ & 41 & 16 & 43 & 39 & 27 & 166 \\
$35-39$ & 45 & 21 & 42 & 39 & 19 & 166 \\
$40-44$ & 35 & 20 & 33 & 33 & 22 & 143 \\
$45-49$ & 24 & 15 & 51 & 28 & 21 & 139 \\
$50-54$ & 35 & 14 & 40 & 45 & 10 & 144 \\
$55-59$ & 34 & 14 & 31 & 38 & 16 & 133 \\
$60-64$ & 34 & 13 & 17 & 34 & 7 & 105 \\
$65-$ & 119 & 26 & 68 & 84 & 42 & 339 \\
All & 395 & 148 & 352 & 366 & 175 & 1,436
\end{tabular}

